\title{
Pembinaan Siklus Akuntansi Perusahaan Dagang Dan Jasa Dengan MYOB Accounting V17 Pada SMK Batam Business School
}

\author{
Tukino Tukino $^{1 *}$, Baru Harahap ${ }^{2}$ \\ ${ }^{1}$ Jurusan/Program Studi Sistem Informasi , Fakultas Teknik dan Komputer \\ ${ }^{2}$ Jurusan/Program Studi Akuntansi , Fakultas Ilmu Sosial dan Humaniora \\ ${ }^{1,2}$ Universitas Putera Batam, Jalan R. Soeprapto Muka Kuning, Kibing, Kec. Batu Aji, \\ Kota Batam, Kepulauan Riau 29434 \\ *e-mail : tukino@puterabatam.ac.id
}

Informasi Artikel

Diterima Redaksi : 2 Februari 2021

Revisi Akhir : 28 Maret 2021

Diterbitkan Online : 30 Juni 2021

Kata Kunci:

Pembinaan; Siklus Akuntansi; Perusahaan Dagang Dan Jasa

\section{PENDAHULUAN}

SMK merupakan pendidikan pada jenjang menengah yang mengutamakan pengembangan keterampilan siswa. Keterampilan yang dimiliki merupakan hasil dari pembelajaran di sekolah maupun di industri. Dunia industri berperan penting dalam proses pembelajaran di SMK, yaitu dengan bekerjasama dalam pelaksanaan praktik industri. Praktik industri bagi siswa SMK merupakan ajang menerapkan ilmu yang pernah diperoleh di bangku sekolah. Siswa juga akan mendapatkan ilmu baru di

\section{Abstrak}

SMK yang berlokasi saling berdekatan, tetapi belum sinergi dalam pemanfaatan sumber daya yang ada di masing-masing sekolah dipandang kurang efisien. Di sisi lain beberapa SMK mempunyai sumber daya yang memadai dan cukup potensial untuk memperluas dan sekaligus meningkatkan pelayanan pendidikan terhadap masyarakat melalui berbagai program pendidikan dan latihan. Berkaitan dengan kondisi tersebut, Direktorat Pembinaan Sekolah Menengah Kejuruan memprogramkan untuk menggabungkan sekolah tersebut dalam satu manajemen dan meningkatkan daya tampung SMK melalui berbagai program pendidikan dan pelatihan dengan nama Pengembangan SMK Besar. Laporan Keuangan berfungsi sebagai alat untuk menganalisis kinerja keuangan yang dapat memberikan informasi tentang posisi keuangan, usaha, kinerja dan arus kas sehingga dapat dijadikan dasar membuat keputusan-keputusan ekonomi. Objek pengabdian ini, ditujukan kepada Sekolah Menengah Kejuruan (SMK) Batam Business School di sekitar Kelurahan Sekaran yang mayoritas pelaku Sekolah Menengah Kejuruan (SMK) Batam Business School belum memiliki laporan keuangan. T labaujuan program pengabdian ini adalah memberikan pelatihan kepada pelaku Sekolah Menengah Kejuruan (SMK) Batam Business School dalam penyusunan akuntansi berbasis Standar Akuntansi Keuangan Entitas Tanpa Akuntabilitas Publik (SAK ETAP) serta untuk merancang sistem akuntansi sederhana secara manual maupun terkomputerisasi yang dapat membantu dan memudahkan para pelaku Sekolah Menengah Kejuruan (SMK) Batam Business School dalam membuat laporan keuangan berbasis SAK ETAP.

industri, karena mereka belajar pada kondisi nyata dengan suasana kerja yang sebenarnya. Selesai melaksanakan praktik industri siswa akan disibukkan berbagai kegiatan yang harus dilaksanakan untuk kelulusannya. Siswa sekolah menengah kejuruan dinyatakan lulus jika mereka berhasil menyelesaikan Ujian Sekolah, Ujian Nasional dan Uji Kompetensi siswa.

Dalam rangka mendukung dan penyelenggaraan pendidikan serta untuk meningkatkan kompetensi siswa, serta menciptakan lulusan yang siap pakai sesuai 
dengan tuntutan dunia usaha dan dunia industry, maka diselenggarakan praktek uji kompetensi sebagai cara untuk mengukur uji kompetensi peserta didik. Pelaksanaan uji kompetensi tahun pelajaran 2016/2017 telah diatur sedemikian rupa dalam keputusan standar nasional pendidikan 0022/P/BSNP/XI/2013 tentang POS Uji Kompetensi Keahlian SMK. SMK Batam Business School sangat mendukung program bantuan praktik uji kompetensi yang diselenggarakan oleh dinas pendidikan Kota Batam. Kami yakin dengan program tersebut maka kita semua dan pihak-pihak concern terhadap perkembangan pendidikan khususnya SMK Batam Business School akan lebih leluasa untuk meningkatkan kualitas sumber daya manusia (SDM). SMK yang berlokasi saling berdekatan, tetapi belum sinergi dalam pemanfaatan sumber daya yang ada di masing-masing sekolah dipandang kurang efisien. Di sisi lain beberapa SMK mempunyai sumber daya yang memadai dan cukup potensial untuk memperluas dan sekaligus meningkatkan pelayanan pendidikan terhadap masyarakat melalui berbagai program pendidikan dan latihan. Berkaitan dengan kondisi tersebut, Direktorat Pembinaan Sekolah Menengah Kejuruan memprogramkan untuk menggabungkan sekolah tersebut dalam satu manajemen dan meningkatkan daya tampung SMK melalui berbagai program pendidikan dan pelatihan dengannama Pengembangan SMK Besar. Optimalisasi pemanfaatan sumber daya pendidikan merupakan salah satu altlernatif yang dapat dilakukan dalam peningkatan efektivitas dan efisiensi dalam pengelolaan sekolah. Implementasi pengembangan SMK Besar ini dapat dilakukan dengan meningkatkan daya tampung sekolah melalui penambahan rombongan belajar atau penggabungan SMK yang berdekatan [4].

Laporan Keuangan berfungsi sebagai alat untuk menganalisis kinerja keuangan yang dapat memberikan informasi tentang posisi keuangan, usaha, kinerja dan arus kas sehingga dapat dijadikan dasar membuat keputusan-keputusan ekonomi. Objek pengabdian ini, ditujukan kepada SMK Batam Business School di sekitar Kelurahan Sekaran yang mayoritas pelaku SMK Batam Business School belum memiliki laporan keuangan. Tujuan program pengabdian ini adalah memberikan pelatihan kepada pelaku SMK Batam Business School dalam penyusunan akuntansi berbasis Standar Akuntansi Keuangan Entitas Tanpa Akuntabilitas Publik (SAK ETAP) serta untuk merancang sistem akuntansi sederhana secara manual maupun terkomputerisasi yang dapat membantu dan memudahkan para pelaku SMK Batam Business School dalam membuat laporan keuangan berbasis SAK ETAP. Pengambilan data dilakukan dengan cara studi pustaka. SMK Batam Business School mengalami kendala dalam penyusunan laporan keuangan dikarenakan kurangnya SDM yang memiliki kemampuan dalam bidang akuntansi dan kurangnya alokasi waktu dalam menyusun laporan keuangan. Hasil penyusunan laporan keuangan berdasarkan SAK ETAP berupa laporan laba rugi, laporan perubahan posisi keuangan, laporan perubahan ekuitas, dan laporan arus kas. Tujuan dari pengabdian ini yaitu mempersiapkan tenaga profesional akuntansi dalam SMK Batam Business School agar bersaing menghadapi MEA 2018 [1].

Berdasarkan hasil wawancara dengan guru mata pelajaran komputer akuntansi kelas XI di SMK Batam Business School, diketahui bahwa selama proses pembelajaran masih menggunakan metode ceramah, diskusi dan pemberian tugas. Kegiatan pembelajaran menggunakan media yang sudah tersedia seperti papan tulis. Selain itu, tidak ada media yang mendukung materi pembelajaran di dalam kelas seperti, gambar bagan, poster dan media lainnya yang berkaitan dengan materi pembelajaran sehingga hasil belajar siswa pun cenderung rendah. Komputer akuntansi adalah salah satu mata pelajaran dijurusan akuntansi kelas XI semester 1 dan 2 dan kelas XII semester 1 siswa SMK Batam Business School. Software yang digunakan dalam pengolahan data akuntansi dalam komputer adalah MYOB (Mind Your Own Business) Accounting versi 17 dengan kompetensi inti perusahaan jasa pada semester 1 dan perusahaan dagang pada semester 2 kelas XI sedangakan di semester 1 kelas XII adalah perusahaan manufaktur [3].

Berdasarkan hasil uji soal, nilai siswa pada uji blok materi Pengolahan Perusahaan jasa semester ganjil di SMK Batam Business 
School Tahun Pelajaran 2017/2018 dapat diketahui bahwa hasil belajar siswa belum tuntas. Hal ini dapat dilihat berdasarkan tabel di bawah ini:

Tabel 1 Nilai Siswa Kelas XI AK 1 dan Kelas XI AK 2 Mata Pelajaran Komputer Akuntansi (MYOB Accounting v17) SMK Batam Business School

\begin{tabular}{ccccc}
\hline \multirow{2}{*}{ No } & \multirow{2}{*}{ Kelas } & \multicolumn{2}{c}{ Interval Nilai } & \multirow{2}{*}{$\begin{array}{c}\text { Jumlah } \\
\text { Siswa }\end{array}$} \\
\cline { 2 - 4 } & & 70 & $\geq 70$ & 40 \\
\hline 1. & XI AK 1 & 15 & 25 & 49 \\
\hline \multirow{2}{*}{ Xumlah } & XI AK 2 & 18 & 19 & 37 \\
\cline { 2 - 4 } & Siswa & 33 & 44 & 77 \\
\cline { 2 - 4 } & Presentase & $42,9 \%$ & $57,1 \%$ & $100 \%$ \\
\hline
\end{tabular}

Sumber: Dokumentasi Guru Mata Pelajaran Komputer Akuntansi (MYOB v17).

Berdasarkan tabel 1, dapat diketahui bahwa dari 77 siswa sejumlah 33 siswa atau $42,9 \%$ belum memenuhi standar nilai Kriteria Ketuntasan Minimum (KKM) yang berlaku di mata pelajaran komputer akuntansi yang telah ditetapkan di SMK Batam Business School yaitu 70.

Penetapan tujuan laporan keuangan merupakan hal yang sangat penting sebelum laporan keuangan itu disusun dan disajikan untuk kepentingan berbagai pihak yang membutuhkannya. Penetapan tujuan laporan keuangan meliputi kegiatan kegiatan seperti mengidentifaksi siapa pemakai laporan keuangan, mengidentifikasi keputusan apa saja yang dilakukan oleh pemakai laporan keuangan dan kebutuhan informasinya baik jenis maupun banyaknya. Dengan mengetahui tujuan laporan keuangan akuntan dapat menentukan kriteria kriteria yang diperlukan untuk menghasilkan caracara terbaik dalam melaporkan informasi yang dicantumkan dalam laporan keuangan tersebut. Dengan demikian laporan keuangan akan berdayaguna sebagai dasar untuk pengambilan keputusan pemakainya. Kegiatan Pengabdian ini yang berjudul "Pembinaan Siklus Akuntansi Perusahaan Dagang Dan Jasa Dengan MYOB Accounting v17 Pada SMK Batam Business School" [2].

Faktor yang menjadi penyebab kesulitan belajar adalah malas untuk mengulang pelajaran yang telah disampaikan oleh guru saat berada di rumah, kurangnya minat belajar, kurang teliti, rendahnya tingkat ingatan, pemahaman dan kondisi mental, dan faktor fasilitas sekolah dan guru mata pelajaran. Berdasarkan permasalahan ini dapat disimpulkan bahwa faktor paling dominan yang menyebabkan kesulitan belajar 18 siswa kelas XI AK2 Program Keahlian Akuntansi pada mata pelajaran Aplikasi Komputer Akuntansi (MYOB) adalah faktor malas untuk belajar, dan\& guru yang kurang membimbing siswa yang mengalami kesulitan belajar secara continue dan individual. Materi yang paling banyak kurang dipahami siswa kelas XI AK2 Program Keahlian Akuntansi (MYOB) pada mata pelajaran Aplikasi Komputer Akuntansi (MYOB) adalah materi Mengentri Bukti Transaksi. Juga dapat disarankan kepada siswa agar memiliki motivasi untuk belajar dan keinginan belajar yang kuat, kepada guru harus membimbing siswa yang diduga mengalami kesulitan belajar secara intens dan individual, serta hendaknya siswa melakukan latihan berulang-ulang terhadap materi-materi yang memiliki langkah-langkah yang panjang

\section{METODE}

Untuk metode pelaksanaan kegiatan pembinaan sendiri ada beberapa hal yang perlu dilakukan diantaranya adalah sebagai berikut:

1. Melakukan pendataan peserta pembinaan pada SMK Batam Business School yang hadir ditempat acara untuk didata identitasnya laki-laki atau perempuan

2. Dilakukan pemaparan materi oleh Dosen

(Ketua), Dosen (Anggota) dan Mahasiswa (Anggota) dilanjutkan dengan istirahat sambil ramah tamah dengan peserta pembinaan pada SMK Batam Business School.

3. Ketercapaian tujuan pelatihan penyusunan laporan keuangan sederhana bagi orang-orang yang bekerja pada industri kreatif secara umum sudah berjalan dengan baik, namun keterbatasan waktu yang disediakan mengakibatkan beberapa materi tentang laporan keuangan masih kurang dalam praktik penyusunannya.

Kegiatan Pengabdian Kepada Masyarakat yang dilaksanakan secara tatap muka dan praktek penyusunan laporan keuangan berjalan dengan baik dan lancar. Pelatihan ini dimulai dengan metode ceramah dan pemberian contoh penyusunan laporan keuangan. Selanjutnya peserta 
diajak untuk menyusun laporan keuangan sesuai dengan jenis usahanya masingmasing berdasarkan transaksi-transaksi yang telah mereka lakukan.

Pelatihan ini dilaksanakan setiap hari Sabtu, mulai pukul 09.00-11.00 WIB di SMK Batam Business School. Peserta kegiatan berjumlah 20 orang siswa/siswa yang berasal dari SMK Batam Business School khusus jurusan Akuntansi. Pelaksanaan kegiatan Pengabdian Kepada Masyarakat ini dilakukan oleh 3 orang tim pengabdi (Dosen dan Mahasiswa)

\section{HASIL DAN PEMBAHASAN \\ A. Hasil Pengabdian}

Dalam rangka untuk mengaplikasikan ilmu akuntansi kepada masyarakat, Program Studi Akuntansi Universitas Putera Batam pada hari Sabtu pada tanggal 25 Januari dan 01 Februari 2019 yang bertempat di Sekolah Menengah Kejuruan (SMK) Batam Business School diperuntukkan untuk $20 \mathrm{Siswa/Siswi}$ Sekolah Menengah Kejuruan (SMK) Batam Business School untuk jurusan akuntansi saja. Kegiatan ini melibatkan satu orang dosen, yaitu: Tukino, S.Kom., M.SI. dan Bapak Baru Harahap, S.E., M.Ak, satu orang Mahasiswa Program Studi Akuntansi. Kegiatan ini dihadiri oleh Kepala Sekolah Sekolah Menengah Kejuruan (SMK) Batam Business School, dan 20 Siswa/Siswi Sekolah Menengah Kejuruan (SMK) Batam Business School untuk jurusan akuntansi saja.

Pada awal acara, Bapak Osriza Betri, S.S., M.M selaku Kepala Sekolah Menengah Kejuruan (SMK) Batam Business School dalam sambutannya menegaskan bahwa kegiatan ini sangat penting untuk menambah wawasan Siswa/Siswi Sekolah Menengah Kejuruan (SMK) Batam Business School untuk jurusan akuntansi tentang akuntansi dalam pelaporan keuangan, sehingga diharapkan Siswa/Siswi Sekolah Menengah Kejuruan (SMK) Batam Business School untuk jurusan akuntansi dapat memanfaatkan kesempatan ini dengan sebaik-baiknya. "Terimakasih kepada tim dari Universitas Putera Batam yang telah menyempatkan waktunya untuk memberikan pengetahuan pada warga kami," tuturnya. Dalam sambutannya Bapak Baru Harahap, S.E., M.Ak selaku Dosen
Program Studi Akuntansi Universitas Putera Batam menyampaikan ucapan terimakasih atas sambutan yang telah diberikan kepada tim dari Universitas Putera Batam dan menyatakan akan selalu siap memberikan bantuan pelatihan dan konsultasi pada berbagai bidang pengetahuan yang berhubungan dengan akuntansi dan auditing, seperti akuntansi sektor publik yang mungkin dibutuhkan oleh Siswa/Siswi Sekolah Menengah Kejuruan (SMK) Batam Business School untuk jurusan akuntansi.

Pemberian materi dilakukan oleh Tukino, S.Kom., M.SI. dan Bapak Baru Harahap, S.E., M.Ak yang menjelaskan tentang dasardasar pencatatan akuntansi dan pelaporan, seperti cara menjurnal transaksi yang terjadi, mem-postingke buku besar, membuat neraca saldo, dan membuat laporan laba rugi bagi Siswa/Siswi Sekolah Menengah Kejuruan (SMK) Batam Business School untuk jurusan akuntansi. Usai pemberian materi, peserta diajak untuk mempraktikkan ilmu yang telah diberikan dengan mengerjakan kasus yang telah disiapkan oleh tim dosen dengan dibimbing oleh seluruh dosen dan mahasiswa. Walaupun kegiatan diadakan di tempat yang terbuka dan dalam suasana panas, namun seluruh peserta dan tim terlihat antusias mengikuti acara ini.

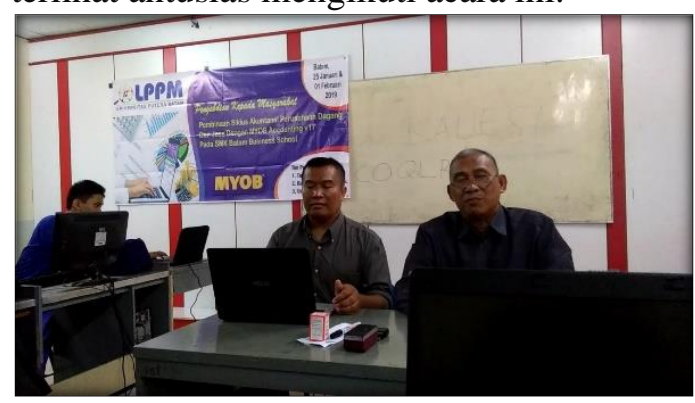

Secara umum acara pelatihan ini berjalan dengan lancar. Hal ini dicapai berkat dukungan Kepala Sekolah Menengah Kejuruan (SMK) Batam Business School yaitu fasilitas tempat serta bantuan dalam mengumpulkan audiens peserta (Siswa/Siswi Sekolah Menengah Kejuruan (SMK) Batam Business School jurusan akuntansi). Kepala Sekolah Menengah Kejuruan (SMK) Batam Business School menyambut baik acara pelatihan ini sehingga berkeinginan agar kegiatan pelatihan ini kepada tetap berlanjut di masa yang akan datang untuk kemajuan siswa/siswinya. 
Pengabdian masyarakat yang berupa pembinaan telah direalisasikan sebanyak 2 kali pertemuan yang dilaksanakan setiap pukul 09.00 sampai dengan 11.00 WIB. Pembinaan dilakukan oleh 20 (dua puluh) orang dari siswa dan siswi SMK Batam Business School. Teknis pelaksanaan pembinaan dilakukan dengan metode ceramah, diskusi dan latihan penyusunan laporan Keuangan. Berdasarkan metode tersebut maka Tim pengabdi secara langsung memandu dan membina siswa dan siswi SMK Batam Business School dalam penyusunan laporan keuangan sesuai dengan SAK-ETAP yang benar. Adapun penjelasan pada setiap pertemuan sebagai berikut:

\section{a) Pertemuan Pertama}

Pelaksanaan pengabdian masyarakat pertemuan pertama dilaksanakan pada Jumat, 25 Januari 2019, dimana kegiatan pertemuan saat itu diawali dengan pembukaan oleh Ketua, dilanjutkan penyampaian materi topik materi Pengantar Akuntansi. Materi ini membahas pentingnya akuntansi disertai membahas soal terkait transaksi serta membahas soal dan jawaban jurnal umum. Kegiatan ini disampaikan oleh Ketua.

Materi kedua ini juga disampaikan oleh Anggota 2 dengan topik transaksi-transaksi, buku besar, neraca akuntansi dan pelaporan akuntansi dengan bantuan menggunakan bantuan computer dalam program $M Y O B$ Accounting $\quad$ 17 untuk mempermudah penginputan data keuangan dalam mempraktekannya. Sedangkan materi ketiga yang disampaikan oleh Anggota 1 terkait jurnal penyesuaian, neraca saldo setelah penyesuaian.

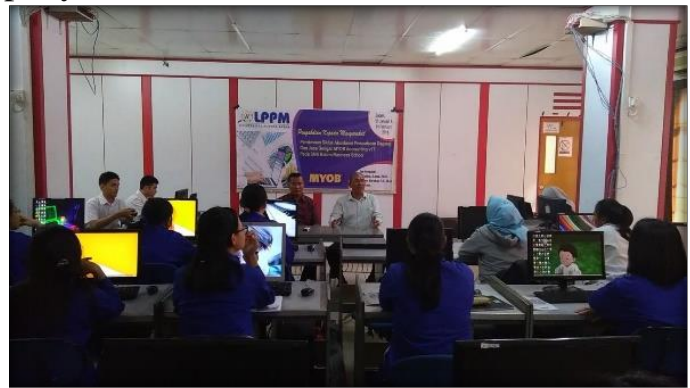

b) Pertemuan Kedua

Pelaksanaan pengabdian masyarakat pertemuan kedua dilaksanakan pada Jumat, 01 Februari 2019. Kegiatan pertemuan ini berupa penjelasan topik praktik akuntansi yang disampaikan oleh Ketua pada pukul 09.00 serta dilanjutkan oleh Ketua terkait penjelasan materi laporan keuangan yang sesuai dengan standar akuntansi keuangan entitas tanpa akuntabilitas publik (SAKETAP) yang terdiri dari laporan laba rugi, laporan posisi keuangan, laporan perubahan ekuitas, dan laporan arus kas. Pada materi laporan laba rugi dan laporan posisi keuangan dibahas jawabannya serta paparannya oleh Ketua. Kemudian setelah itu selesai pada pukul 09.00 sampai dengan 11.00 WIB dilanjutkan pembahasan materi dan contoh soal terkait laporan perubahan ekuitas yang disampaikan oleh Anggota 1, serta materi dan contoh kasus laporan arus kas dibahas oleh Anggota 2. Tepat pada jam 10.00 Tim pengabdi memberikan sesi latihan terkait transaksi bisnis secara mandiri yang didampingi oleh Anggota 1 dan Anggota 2. Tujuannya agar mendapatkan feedback dari yang sudah disampaikan.

Selanjutnya sisa pembinaan peserta diberikan kesempatan untuk mendiskusikan permasalahan yang berkaitan dengan usaha yang sudah mereka jalani yang didampingi oleh Ketua, Anggota 1 dan Anggota 2.

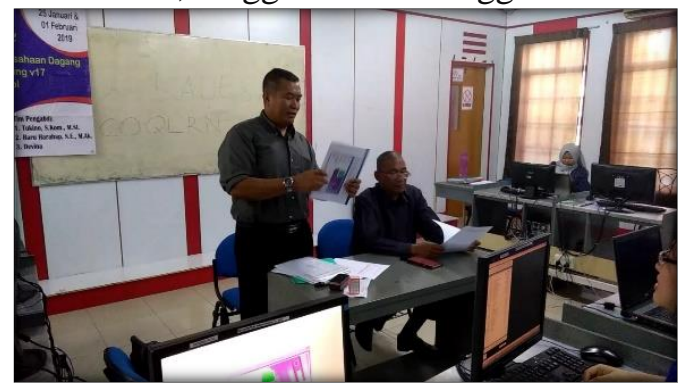

\section{B. Pembahasan}

Kegiatan yang sudah dilaksanakan sebanyak 2 kali pertemuan dapat dijelaskan bahwa kegiatan dapat dijalankan sesuai dengan rencana. Dosen dan dua orang mahasiswanya yang memberikan bantuan kepada membina siswa dan siswi SMK Batam Business School dalam penyusunan laporan keuangan yang berstandar ETAP. Materi pertama yang diberikan adalah pengenalan atau pendahuluan mengenai akuntansi. Pemateri memberikan penjelasan pentingnya akuntansi bagi serta membahas materi dan soal-soal dari jurnal umum sampai dengan laporan keuangan. Sebagian besar audiens belum mengerti fungsi akuntansi, bahkan sebagian besar peserta pembinaan menganggap bahwa akuntansi adalah bidang yang rumit, susah, merepotkan, menghabiskan waktu. 
Materi pertama diisi dengan penguatan pentingnya akuntansi bagi usaha kecil (UMKM) dan data-data transaksi yang harus dimasukan didalam jurnal umum. Pada sesi ini terjadi diskusi yang menarik antara audience dengan pemateri mengenai konsep dasar usaha terkait usaha yang membina siswa dan siswi SMK Batam Business School tekuni. Dilanjutkan materi kedua mengenai transaksi-transaksi akuntansi. Pada sesi ini, masing-masing audience diminta menjelaskan aktivitas operasi masing-masing usaha mereka. Selanjutnya diidentifikasi aktivitas-aktivitas ekonomi terkait pencatatan akuntansi. Aktivitas yang diidentifikasi tersebut diawali dari aktivitas memulai usaha (investasi awal), transaksi pembelian bahan baku, pembelanjaan atau pengeluaran, pemasukan atau penerimaan. Setelah mencatat transaksi akuntansi, materi berikutnya menyusun laporan keuangan. Sebagai latihan, peserta pembinaan diminta untuk menjawab soal latihan yang telah disediakan oleh Tim Pengabdi dengan menjawabnya menggunakan bantuan computer dalam program MYOB Accounting v17. Sesi terakhir peserta diberikan diskusi terkait pencatatan keuangan di usaha UKM.

Pembinaan hari kedua dilaksanakan hari Jumat, 01 Februari 2019, peserta diberikan gambaran tentang materi dan praktik laporan keuangan yang terdiri dari laporan laba rugi, laporan perubahan ekuitas, laporan neraca serta laporan arus kas. Pada sesi awal peserta bertanya dan berdiskusi tentang transaksi dan pencatatan yang telah mereka buat. Beberapa dari peserta masih kebingungan mencatat transaksi akuntansi. Sambil beristirahat dan menyantapi snack yang ada, diskusi dilanjutkan membahas penyusunan laporan keuangan dalam prakteknya. Serta sisa jam 10.00 WIB pembinaan digunakan untuk pendampingan kepada peserta pembinaan akuntansi secara mandiri dimasing-masing tempat untuk menjawab latihan yang telah disediakan Tim Pengabdi.

Pelaksanaan pengabdian yang dilaksanakan ditemukan kendala yang signifikan, namun dapat diatasi setelah kegiatan dilaksanakan sampai selesai, kendala yang terjadi adalah:

a) Sebagian besar peserta menyusun laporan keuangan belum sesuai standar akuntansi keuangan entitas tanpa akuntabilitas publik. b) Kesulitan mencocokan waktu Tim Pengabdi dengan peserta pengabdian.

c) Laporan keuangan yang telah biasa disusun oleh membina siswa dan siswi SMK Batam Business School tidak bisa diganti secara langsung.

d) Penginputan data keuangan dengan menggunakan computer di MYOB Accounting v17 tidak bisa diganti secara langsung.

e) Keikutsertaan atau kehadiran peserta yang relative rendah hanya 6 orang dari 10 orang undangan yang telah dikoordinir oleh Kepala Sekolah SMK Batam Business School.

Permasalahan yang dihadapi Tim Pengabdi diatas dapat dievaluasi dengan cara sebagai berikut:

a) Pelaksanaan ini dapat dijelaskan secara continue, sampai dengan usaha kecil menengah mengerti dengan penjelasan setiap pertemuan yang dilaksanakan sampai dengan siswa dan siswi SMK Batam Business School dapat secara mandiri menyusun laporan keuangan usaha mereka.

b) Kesulitan dari waktu, maka dari itu Tim Pengabdi mencocokan waktu siswa dan siswi SMK Batam Business School dengan Tim Pengabdi. Kesepakatan sudah dibentuk pada awal pertemuan antara siswa dan siswi SMK Batam Business School dengan Tim Pengabdi.

c) Perbedaan yang terjadi dengan apa yang selama ini dijalankan maka, tentunya Tim Pengabdi tidak bisa memaksakan siswa dan siswi SMK Batam Business School untuk dapat dengan segara menyesuaikan penyusunan laporan keuangan sesuai dengan standar akuntansi keuangan entitas tanpa akuntabilitas publik, perlu adanya tahaptahap praktek secara langsung dilakukan oleh siswa dan siswi SMK Batam Business School untuk meninput data keuangan dengan bantuan $M Y O B$ Accounting v17.

d) Laporan keuangan yang mulanya disusun menggunakan manual dengan buku besar yang hanya mencatat berapa pemasukan dan pengeluaran. Dengan perkembangan dunia maka dari itu siswa dan siswi SMK Batam Business School juga dituntut untuk mau mempelajari 
penginputan data keuangan dengan "MYOB Accounting v17". Tim pengabdi melakukan pembinaan penginputan data keuangan dengan dasarnya yaitu bantuan $M Y O B$ Accounting v17 secara praktek mandiri per 6 orang dari siswa dan siswi SMK Batam Business School.

e) Tim pengabdi selalu melakukan koordinasi dan berkomunikasi serta mengevaluasi setiap selesai kegiatan pengabdian masyarakat. Pelaksanaan evaluasi kegiatan dilakukan untuk mengetahui kendala yang dihadapi saat pengabdian dilaksanakan. Hasil evaluasi akan ditindaklanjuti sesuai dengan kendala yang sedang dihadapi.

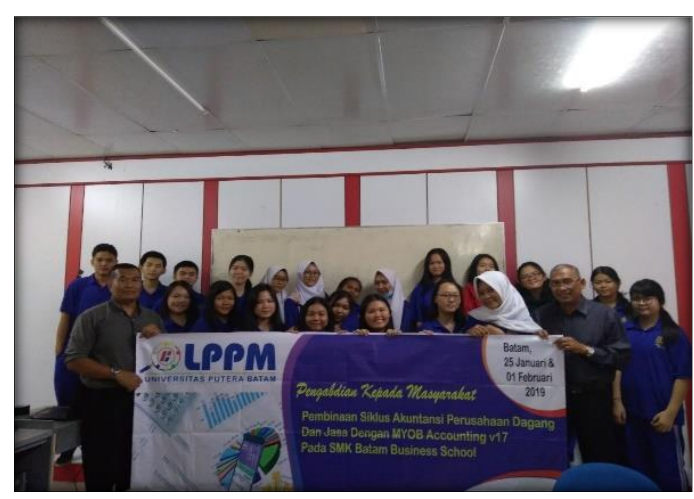

\section{KESIMPULAN}

Berdasarkan penjelasan hasil dan pembahasan, maka didapatkan simpulan sebagai berikut:

a) Dari kegiatan pengabdian masyarakat di bidang teori / penyampaian materi hasilnya cukup baik dan dapat diterima.

b) Dari kegiatan pengabdian masyarakat di bidang pelatihan, untuk pelatihan Akuntansi hasilnya sangat memuaskan.

\section{SARAN}

Berdasarkan kesimpulan kegiatan di atas, maka disarankan kepada Sekolah Menengah Kejuruan (SMK) Batam Business School, antara lain adalah:

a) Kegiatan ini dapat dilangsungkan di Sekolah Menengah Kejuruan (SMK) Batam Business School.

b) Dapat dilakukan pengabdian lebih lanjut dengan materi yang lebih advance.

c) Jangka waktu pelaksanaan agar dapat diperpanjang mengingat sulitnya transfer ketrampilan dalam waktu yang relatif sempit. d) Perlu dana yang lebih besar agar hasilnya lebih optimal.

\section{UCAPAN TERIMA KASIH}

Terima kasih kepada LPPM Universitas Putera Batam sebagai pemberi dana dalam pengabdian ini sehingga pengabdian ini dapat terlaksana dengan baik. Terima kasih kepada SMK Batam Business School yang menjadi objek pengabdian penulis

\section{REFERENSI}

[1]. Jusup. A. H. (2012). Dasar-Dasar Akuntansi Jilid 1 Edisi 5. Yogyakarta: Bagian Penerbitan STIE YKPN.

[2]. Tunggal, A. W. (2013). Akuntansi Untuk Perusahaan Kecil dan Menengah, Jakarta: Rineka Cipta.

[3]. Mardiasmo. (2010). Akuntansi Keuangan Dasar Jilid 1 Edisi 3. Yogyakarta: BPFE UGM.

[4]. Mulyadi. (2013). Sistem Akuntansi Edisi 3. Yogyakarta: Bagian Penerbitan STIE YKPN. 